ESJ Social Sciences

\title{
The Case Study on Significance of Daylight in Classroom Setting at Sarajevo Campus
}

\author{
Ahmed Obralic, PhD \\ Salam Jeghel, Msc \\ International University of Sarajevo, Bosnia and Herzegovina
}

Doi:10.19044/esj.2021.v17n1p19

Submitted: 05 December 2020

Accepted: 12 January 2021

Published: 31 January 2021
Copyright 2021 Author(s)

Under Creative Commons BY-NC-ND

4.0 OPEN ACCESS

Cite As:

Obralic, A. \& Jeghel S. (2021). The Case Study on Significance of Daylight in Classroom Setting at Sarajevo Campus. European Scientific Journal, ESJ, 17(1), 19.

https://doi.org/10.19044/esj.2021.v17n1p19

Abstract

When designing schools, universities, or any educational centers, daylight in classrooms is usually one of the essential issues that take the architect's attention. Its importance comes from the fact that daylight can impact students' health, mood, and visual performance. Providing an appropriate amount of uniformly distributed light with glare protection is a significant factor in classroom design (Zomorodian Z S, 2016). This study is based on a literature review, studies, and articles researching the effect of daylight in a classroom environment on students' performance. It tends to define the significance of daylight design in the learning environment. This paper also deals with specifying and exploring all the conditions, factors, and elements that contribute to creating this successful daylight design in classrooms. Besides, it investigates the daylight design of the buildings at the campus of Sarajevo that will, later on, contribute to the creation of a design manual of all the considerations that need to be taken for schools and educational centers' daylight design. The study is conducted at the campus of Sarajevo in the academic year 2019. The literature review, data study, and previous studies define the significance of daylight in the classroom environment and show the correlation between daylight and students' achievement in the classroom environment. It defines the elements and conditions of successful daylight design in classroom settings. The study explored the current state of the daylight design at the campus of Sarajevo detecting its lacks and obstacles regarding adequate illumination. Based on the 
literature review, an appropriate solution for the investigated classroom environment has been designed.

Keywords: Architectural Faculty, Architectural design, Daylight, Daylight design, Students' performance, Classroom design

\section{Introduction}

The aim of educational facilities, in achieving the best outcome of students learning, cannot be accomplished only through its curriculum, teaching approaches, instructional materials, assessment or the institute management coordination, but also the physical environment which surrounds the students, in classrooms and corridors can have an important role as well (Pulay, 2010). Many elements can be part of the educational physical environment, starting with building form and structure, to follow with color, furniture, materials, light, and view. In many cases, light can have a bigger influence on the environment than other elements. By developing a better understanding of the relationship between light and the learning process, designers and architects can enhance the interior design and improve the academic performance of students (Samani \& Samani, 2012).

The process of creating successful daylight in classrooms requires very deep consideration of many aspects and from the very beginning of the project because it involves studying the building's location, climate, functional requirements, orientation, making decisions about the arrangement of building openings (doors and windows), shading systems, glazing materials, shading systems, and artificial lighting systems (Ander, 2015). Humans' psychology and physiology both are deeply affected by daylight, and its influence on mood, awareness, vision, and circadian rhythms cannot be denied, as well as its role in the learning course, what makes poorly let classrooms negatively affect students' health and learning ability(Mott, Robinson, Walden, Burnette, \& Rutherford, 2012). Even Wurtman (1975) emphasized the importance of light as food and water in directing our physical functions.

In designing a functional space such as a classroom, where its purpose is essentially dependent on visualization and observation, daylight can have a crucial role in this process, concerning its influence on the visual performance, learning, and the health of the students. Therefore, the designers' job should be directed towards creating an adequate amount of evenly distributed daylight with taking glare and undesirable radiation into consideration (Zomorodian, Korsavi \& Tahsildoost, 2016).

This paper deals with daylight and its factors for so many reasons, the importance of daylight is wide enough to involve many aspects, it provides for us as humans information about the outside world just as valuable as the energy of its radiation, since the human body grew in the diversion of day and 
night, darkness and light, summer, and winter. Having daylight doesn't only connect people with the space around them, it also relates them to the time of the day and fulfills their need to be in touch with the outside world. These daynight, light-dark changes are what regulates the interior clock of the human body, and balance its circadian rhythms, which can cause immediate influence on alertness, sleep, and cognitive performances (Tregenza \& Wilson, 2013). And even though overexposure to sunlight can carry the risk of skin damage, receiving an adequate amount of it will produce vitamin $\mathrm{D}$, which in turn is associated with various beneficial effects, like reducing the risk of cancer and cardiovascular disease (Holick, 2008). The day can also produce serotonin and positively affect the mood (Lansdowne \& Provost, 1998). Besides the daylight advantages on humans' psychologically and physiologically, it can have sustainable and economic benefits as well. Since the proper presence of daylight substitutes any need for electrical light, not only electricity costs will be reduced, it also saves energy, and minimizes carbon dioxide gas emission by using less non-renewable energy sources (Molinski, 2009).

In the learning process, many elements in the physical environment can be influential, such as noise level, thermal comfort, classroom dimensions and volume, walls color, daylight, and illumination. Certainly, all these elements are worth investigating while designing schools to create the best learning atmosphere, thus the research concerns the daylight as a significant part of this environment.

In this regard the following questions are proposed: Is daylight a significant factor in the classroom environment?; What are the elements and conditions of successful daylight design in classroom settings?; Is there an appropriate project design solution for the detected daylight design lacks and obstacles at the faculties of the Sarajevo campus?.

Defining the significance of the daylight for students' academic performance, and understanding the conditions and factors of successful daylight design can help the management boards in schools and educational centers, as well as designers and architects to pay more attention to it, while creating learning environments, what will help to realize their purpose in achieving the best possible outcomes in academic performance of students. Caring about the educational environment is a crucial element in building the counties' infatuation, which will eventually have a valuable reflection on society as well as the countries' development.

\section{Literature review \\ Background of the study}

In respect of the growing concern about green architecture, daylight has become an important design issue (Boubekri, Cheung, Reid, Wang, \& Zee, 2014). Other than the environment's need for natural sources for energy like 
daylight, humans need it as well. Through thousands of years, the human body has evolved through the circle of day and night, light and dark, and is regulated according to the spectrum of the sun's radiation. Human beings respond to daylight in various ways, it can influence their health, and arouse reactions in them that could be traced to their basic need for safety and survival; it can even affect the way they interact with each other, and shape the simplicity in which they can accomplish visual tasks, what makes the light more than a flow of constant light but something dynamic, which can change according to time and place (Tregenza \& Wilson, 2013). All these together make daylight an essential part of architectural design. This is especially enhanced in the case of schools and classrooms to create an optimal environment for students and to improve their ability to concentrate and pay attention, especially since visual tasks like reading and writing are important and take a good amount of their time inside these classrooms. This study also highlights the relationship between daylight and students' academic performance. Also, it is conducted to create a clear understanding of the relationship between architecture and daylight, how daylight and architecture are integrated at each stage of building design.

\subsection{Significance of the Daylight}

With the recent growing concern about global warming, the environment, carbon emission, and the creation of sustainable design, relying on daylight for non-commercial buildings has become a crucial step in the direction of energy-efficient buildings. This is achieved by minimizing the use of artificial lighting and controlling thermal loss and gain. The pursuit of advanced, creative daylighting systems and strategies can significantly decrease the consumption of electricity and enhance daylight level within the building. The importance of daylight can be found in literature and researches as much as in the observation of human behavior and the interior arrangement of home and office spaces (Ruck, et al., 2000).

Windows are considered important for the view it provides, which connects the inside with the outside environment. Daylight is also essential because of its lighting quality, changeability, and spectral composition. A study on human's reaction to interior environment revealed that daylight is preferred to fulfill two primary human's necessities: first like providing the visual comfort for accomplishing a task or see the interior space, and second to be able to experience some environmental stimulation (Boyce, 1998). Spending long hours in schools or workplaces working under electrical lighting conditions is believed to be harmful to health. Also, daylight can help lower stress and create a more comfortable environment. Daylight can originate conditions for good vision by providing a high level of luminance and allowing excellent color recognition and color rendering. But still, 
daylight design without proper considerations about shading and protection can be the reason for high luminance and uncomfortable glare (Ruck, et al., 2000).

Along those lines, Lam \& Ripman (1992) suggest that “... when all buildings were designed around a single, fixed light source (the sun) the difference between great architecture and mere building could be measured to a large degree by the skill with which that source was used. The shapes and sizes of rooms, and the materials and details in them, were determined largely by the appearance the room would take on when rendered by daylight" (p.11).

\subsubsection{Significance of the Daylight: Providing View}

Having access to the natural view is believed to be advantageous in a wide range of ways. According to research in the field of physical well-being and health care, natural views that are attainable through windows can positively affect the occupants' health outcomes (Devlin \& Arneill, 2003).

For providing the view, windows' details like their size, position, frame, or other elements concerning the occupants' eye level should be carefully considered. Also, the daylight design could affect the view. And when providing visual contact with the outside environment is not a priority in daylight design, the exterior shading elements can block the occupant view. Therefore, advanced daylight strategies can pay attention to this issue, assigning different functions to the suitable areas of the facades for maintaining view windows without compromising them to other functions (Ruck et al., 2000).

The study done by Benfield, Rainbolt, Bell, \& Donovan (2015) is intended to examine the differences between college writing course students in two identically designed classrooms, but the first one has a view of nature while the second one has a view of a concrete retaining wall. As suspected results indicated, that students in the classroom with a natural view not only rated the course more positively, they also scored higher results at the end of the semester, compared to other students in the classroom with the view of a retaining concrete wall. These findings point out that classrooms with natural views can offer positive influences. Besides, natural elements in the classroom can increase students' level of perception and their academic performance.

Also Kaplan (1993) had reported two different studies regarding the presence and the absence of natural view windows. In the first one, workers in the office with natural view windows revealed less common health issues during the 6-month work period, while expressed more job satisfaction. And in the other study, natural view windows were related to a growing sensation of privacy and comfort. It is also reported to be linked with decreasing the level of anxiety and frustration, with promoting patience and task enthusiasm. 
Coherent with many other studies in schools, residence buildings, offices, and hospitals, enough evidence has been gathered to confirm the advantages of natural view on the occupants' psychology as well as their physical health. These findings can be used in architectural designs, especially in the case of schools and workplaces, for their role in improving humans' performance (Devlin \& Arneill, 2003).

\subsubsection{Significance of the Daylight: Health}

Through thousands of years, the human body developed and evolved in the day-night diurnal cycle, and it is even possible to state that the human body is tuned to the sun radiation. We react to daylight in different ways; the surrounding environment can influence our well-being and provoke reactions that can be related to our primitive need for safety and survival. Through its stimulation and changeability during the day, daylight is believed to decrease stress levels and enhance productivity (Tregenza \& Wilson, 2013).

The sun radiation can be both harmful and beneficial for the human body. The harmful influence can be either immediate such as sunburn, or longterm disease, like the stimulation of cancer growth. Therefore, there needs to be a balance in the level of sun exposure for the body to get valuable benefits while avoiding the risk (Aries, Aarts, \& van Hoof, 2015).

The importance of daylight is concealed in the natural 24-hour cycle of dark-light, which regulates the body's daily particular order of physiological changes starting from hunger, sleep, body temperature, attentiveness, and most of the hormone production. In mammals' bodies, circadian rhythms are working like 'clocks' managing these changes. Disturbing them can cause sleep disorders and feelings of jetlag. There can even be more severe longterm sequels, for example in prisons windowless cells can be partly responsible for mental health disorders (Tregenza \& Wilson, 2013).

\subsubsection{Significance of the Daylight: Psychology}

For psychologists, there has been a long-lasting and constant concern with the relationship between the outdoor environment and the behavior of human beings at different life stages, in schools, workplaces, homes, prisons, and hospitals (Veitch \& Galasiu, 2012). Recently there has been accumulated evidence regarding the alertness effect of lighting, besides its role in regulating the circadian system. Due to the technological progress in FMRI (functional magnetic resonance imaging), it has been possible to discover the regular form of brain activity as a reaction to light exposure which some researchers of previous generations were not able to present. Even though they always believed in the role of light in inciting cognitive functions Gifford, Hine, \& Veitch (1997) organized a meta-analysis of studies concerning the correlation between light and workers performance in office space with findings of a mild 
connection between them, but this relationship was attenuated because of existing possibility for adapting to the level of light. The studies done by FMRI revealed that daylight exposure during the daytime would raise subjective attentiveness and improve functions in the posterior thalamus, separately from visual responses; it can even motivate action in cortical areas in charge of performance on an auditory task (Vandewalle et al., 2006).

Moreover, the areas of the brain activated by light can change depending on the light intensity level and the length of the exposure. In higher intensity and longer exposure, brain activation would last longer (Vandewalle, Gais et al., 2007; Vandewalle, Schmidt et al., 2007). Even though a high level of light directed on a task can improve visibility, erratic light spread in the eye would cause discomfort and deteriorate visibility.

The literature and researches (Dubois, 2009; Pineault \& Dubois, 2008) about the relationship between glazing type and interior perceptions distinguished the existence of a paradox, which reveals that the same environmental conditions regarding daylight which generated feelings of beauty and pleasantness, were also associated with feelings of discomfort. This paradox can cause design conflict in architecture regarding daylight, except in cases where users can control the shading systems, during different times of the day, depending on their need.

A series of applied and fundamental studies in 2003, assured the CIE that the exposure of people in industrialized countries to the high level of daylight would enhance their mood (Veitch \& Galasiu, 2012). Also, worth mentioning seasonal affective disorder (SAD) which is described as a depressive illness, varies according to the seasonal change during the year. It usually starts during autumn and continues until the end of winter. Accompanied with the usual symptoms of mental depression like lack of energy, mood change, overeating and oversleeping, and the disorder is found mainly among young adults, it can also affect older ones, and it is more likely to influence women than men (Tregenza \& Wilson, 2013).

SAD can be explained by the neurotransmitter serotonin, whose activity increases after being exposed to high luminance. A study was done on genially seasonal women (women whose scores on personality inventory imply that they get mild levels of unhappy feelings during cold season) investigated the influence of light on their system, after inducing their acute tryptophan depletion. The results revealed that their mood dropped when being exposed to dim light (10lx) but it did not drop while being exposed to strong light (3000lx)(aan het Rot, Benkelfat, Boivin, \& Young, 2008).

To sum up, daylight can increase the ability of workers and people to focus by increasing their alertness besides improving their visual tasks. Light can reduce depression levels and improve cognitive performances according to place and time of the day. 


\subsubsection{Sustainable Significance of the Daylight}

Other than the beneficial characteristics of daylight on humans' psychology and well-being, its sustainable role in saving energy and electrical energy costs has made it increasingly popular among architects and designers. The world has been recently attentive to the issues of carbon emission, global warming, and sustainability. The planned use of daylight in buildings has become an essential step toward improving energy efficiency, through cutting down artificial lighting as well as heating and cooling loads. Integrating smart, innovative daylighting strategies in the building architectural design would significantly reduce electricity consumption while enhancing the light quality of the interior environment (Ruck et al., 2000).

By exchanging the buildings' reliance on natural resources (such as daylight) instead of fossil fuels, it would be possible to significantly decrease the burning of greenhouse gases. Luminance is considered one of the biggest consumers of electricity, which makes it one of the main reasons for the emission of carbon dioxide. Lighting consumption of electricity is almost the same as the amount produced by all gas fires generation and around $15 \%$ more than that generated by hydro or nuclear power (Velux, 2016).

It is described that the biggest consumer of lighting electrical energy are the tertiary-sector buildings. For their interior illumination, it spends as much as residential and industrial sectors combined. "On average, lighting accounts for $34 \%$ of tertiary-sector electricity consumption and $14 \%$ of residential consumption in OECD countries, and in non-OECD countries, these shares are usually higher"(OECD. Publishing, \& International Energy Agency, 2006, para.14).

\subsection{Background studies}

Many studies and experiments in schools investigated the effect of daylight on students' academic outcomes. Some of them were specifically analyzing the daylight effect, while others were broader, and studied the effect of the physical environment on students' academic performance while covering daylight.

The study done by Tanner (2008) was intended to examine the effect of school design on students' academic performance. The study compared the achievement of students in three design categories: movement and circulation, daylighting, and views. To quantify the effect of the physical environment on the students' academic results, the study has been conveyed through a reliable set of data. A sample of 71 schools was used, and the measure of these three different school designs was attained by a ten-point Likert scale. Students' outcomes were determined through six parts of the Iowa Test of Basic Skills (ITBS), by assessing reading comprehension, reading vocabulary, language arts, mathematics, social studies, and science. Through its finding, this study 
was able to mark by mathematical scores the positive effect of daylighting on both science and reading vocabulary outcomes. It managed, through employing the concepts, rationale, and methods, to complement other previous researches made to elucidate the impact the physical environment has on students' learning. Through these study findings, which were obtained from its sample, it was proven that schools are much more than boxes where education occurs, but the architectural design can make a difference in a student's academic achievements.

Another study is one of the most important researches done regarding this topic. Research by Heschong, Wright, \& Okura (1999) has been done to find out whether there is a clear relationship between the presence of daylight in schools and students' academic performance. Through multivariate linear regression analysis, the study analyzed the daylighting conditions in more than 2,000 classrooms, and went through 21,000 school records, from 3 schools in 3 different American states examining the performance of students in similar buildings but different daylighting conditions. When studying the impact of daylight on human behavior, schools are the ideal place to go, because of the pre-existing productivity records that can be analyzed and compared between different schools and classrooms with or without skylights, and with various range of daylight conditions. The most important thing was finding ideal organizations that can provide information and data sets that are susceptible to analysis. In findings, the data revealed that students in most daylighted classrooms advanced $20 \%$ faster in math tests and $26 \%$ in reading tests throughout a year than those with least daylit classrooms. Likewise, in classrooms with the largest windows, students progressed 15\% faster in math and $23 \%$ in reading, than students in classrooms with small windows. And in classrooms with openable windows, students advance from 7 to 18 percent than students in classrooms with fixed windows, regardless of airconditioning. These results presented to be solid and consistent regardless of teaching skills or curricula. A regularly positive and highly significant correlation between students' performance and the presence of daylight in all three districts was found. Daylight accessible from skylights distinct from all other apertures linked with windows has a positive effect on human behavior. In all the examinations and observations done in schools, it was obvious and clear that successful daylight design was careful about allowing direct sunlight into classrooms, and more concerned with protecting the students from glare and uncomfortable high illumination. Mostly, designers of the schools intended to make sure for classrooms' windows to be deeply protected by shading systems. In some well-designed daylit classrooms, the users were able to gradually modify daylight accessibility through operable blinds.

The study conducted by Nicklas \& Bailey (1996) also had the aim to investigate daylight effect in a classroom environment on the performance of 
students in elementary and middle school in three days lit schools which are known for their innovative design for Johnson County Schools in North Carolina. These schools are designed in a way to maximize daylight availability in the building by using south-facing roof monitors and permitting controlled daylight entering all the important used spaces within the schools. The roof monitors were applied to provide superior daylight from the top during two-thirds of the time when the schools' spaces are occupied. In any way, these roof monitors were protected by baffles from allowing glare accessing into the interior of the building. Also, the artificial lights are controlled by light sensors, for saving electrical energy. There were also small windows added to the design for providing a view, but they weren't included in the study as a notable component of daylight strategies. The study was mainly concerned with reviewing students' performance improvement in each school, from one year to the next one. It also analyzed students' performance relative improvement in one new middle school but has a non-day lit design. It is constructed in the county around the same time as these three daylit schools. Standardized tests taken from the county school system were assessed and findings showed that students in daylit schools advance the students in non-day lit schools by 5 to 14 percent counting on whether it is considered for long or short-term effects. When examining the improvement rate in all the reference classes in all three daylit schools, the average enhancement of students' outcomes was $4.7 \%$, but the pupils were followed up over a longer time, and the impact was even more.

Küller \& Lindsten (1992) examined the influence of daylight versus a kind of fluorescent light on school students' production of stress hormones, classroom performance, growth of the body, and getting sick. In this study, 90 school children took part in the study in two different schools. They were observed in their environment for one year long. The schools are located in the southern part of Sweden, in a quiet suburb of Malmo, a few hundred meters apart. This zone is known for having cloudy and rainy weather during autumn and winter, and longer days of clear sky, in summer and spring. In this region daylight difference between summer and winter is more than ten hours. The children were distributed into four classrooms, which vary in daylight conditions and type of artificial lighting. The methodology used in this research incorporates observation and the analysis of students' morning urine for inspecting the level of the stress hormone cortisol. These investigations were executed regularly throughout the year, and also records of growth and sick leaves were attained and analyzed at the end of the study. Measurements were obtained in the middle or second half of every school week. Findings indicated that students in windowless classrooms or classrooms that lack adequate lighting may suffer from a disturbance in their chronobiological system which regulates the production of hormones. Students who experience 
more daylight in their classrooms have higher values of cortisol than students in windowless classrooms. This can affect their body growth as well as their health since it was also revealed that students with a higher level of cortisol were linked with lower rates of sick leave. This can be explained by the role of cortisol as a tool to mobilize the body's defense system.

\section{Methodology}

This research study takes the form of a descriptive method and site observation. The descriptive method is based on the observation and analysis of three faculties placed at the campus of Sarajevo.

\subsection{Method of Data Collection}

Data of this case study has been collected through direct observation and site visits. A collection of photos taken from the site, investigating the target buildings, and presenting the important design features are presented in this study. Through data analyzes and literature reviews finding all design issues regarding daylight in these buildings were detected.

\section{Case Study: Architectural faculty \\ Project Location}

Sarajevo is the capital of Bosnia and Herzegovina, considered to be the largest city with a population of 275,524 placed within its administrative limits. Due to its rich history, Sarajevo is largely known for its diversity culturally and religiously, and even called sometimes as "Jerusalem of Europe" or "Jerusalem of the Balkans". One of the few cities in the world where you have a Catholic church, Orthodox church, a mosque, and synagogue within the same locality (Augustyn, 2019). Sarajevo described having a humid continental climate, experiencing large seasonal temperature differences. It is also influenced by oceanic zones, causing it to experience uniformly spread precipitation, along the four seasons. The average yearly temperature is $10^{\circ} \mathrm{C}\left(50^{\circ} \mathrm{F}\right)$, with January $\left(-0.5^{\circ} \mathrm{C}\left(31.1^{\circ} \mathrm{F}\right)\right.$ on average $)$ being the coldest month of the year and July $\left(19.7^{\circ} \mathrm{C}\left(67.5^{\circ} \mathrm{F}\right)\right.$ on average $)$ the warmest (IgorLacan, 2009). 


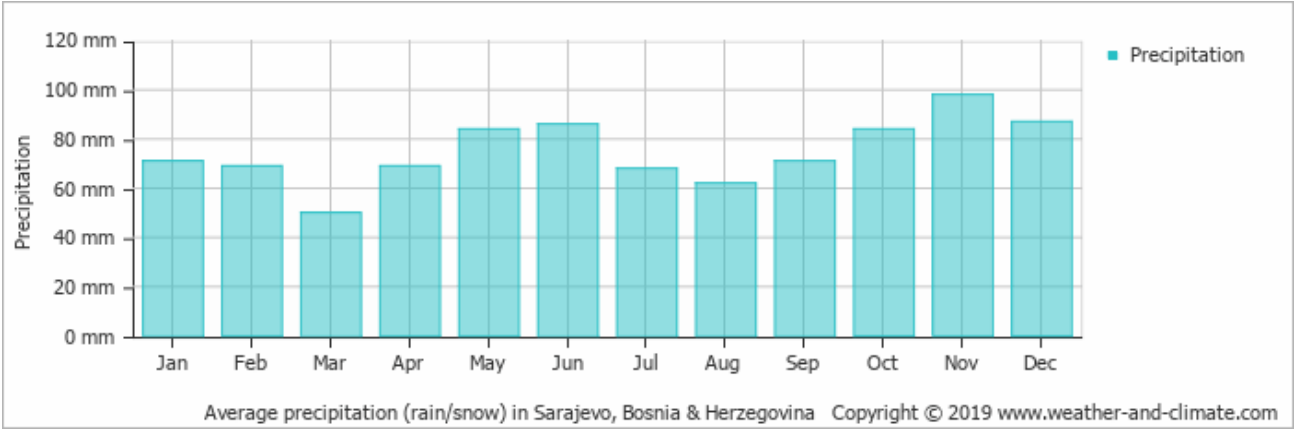

Figure 1. Sarajevo Precipitation Chart

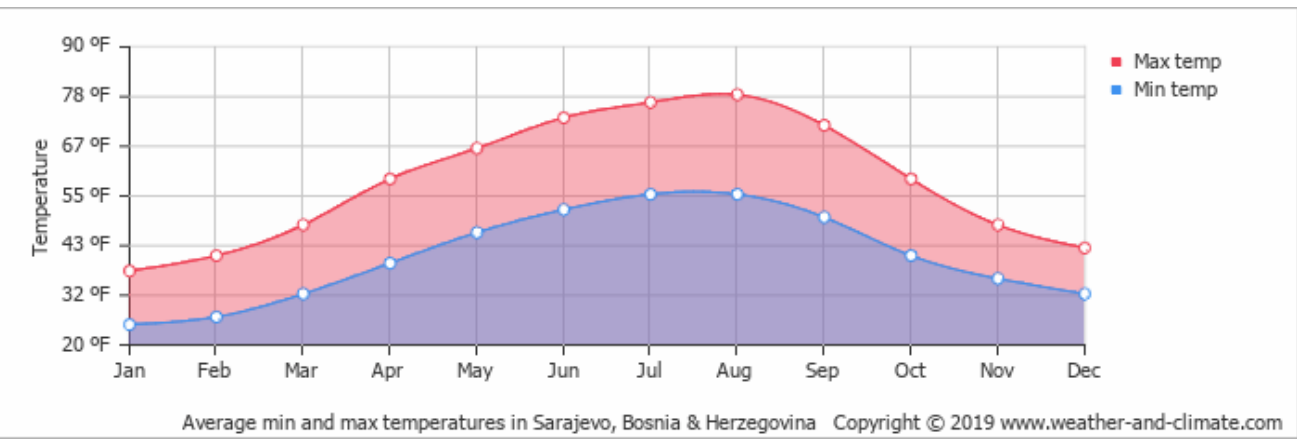

Figure 2. Sarajevo Temperature Chart

When it comes to cloudiness, Sarajevo can be described as a partly cloudy area, with an average year-round value of 59\%. The cloudiest month to be in December 75\%, while August would be the least. With December to have 41 sunny hours and August to have 270 sunny hours, according to the year-round average, Sarajevo has 1830 hours of sunny hours, which classify it as a medium sunny city (weather-and-climate, 2019).

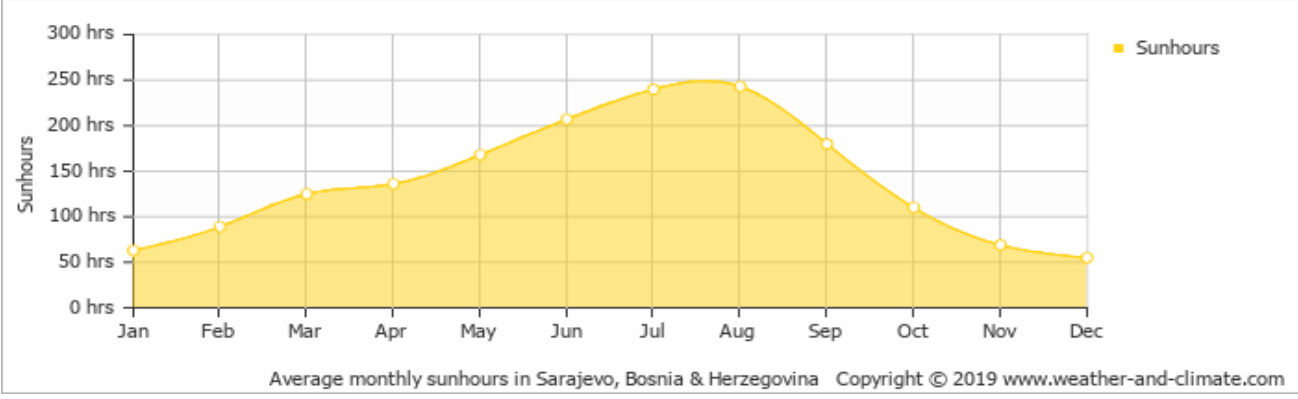

Figure 3. Sarajevo Sun Hours Chart

\subsection{Site Analysis}

The project is located on a flat site of $181.70 \mathrm{~m}$ long and 47.45 wide. The location has shaped like a rectangle with an area of $10,014 \mathrm{~m} 2$. Situated on the Northern part of the campus of the University of Sarajevo, opposite to 
the faculty of agriculture and food science, along Put Života street. The project site has a very good location near the center of the city. Most of the surrounding buildings in the same location were built in the Austro-Hungarian period, many of them are still devastated from the last war. Currently is surrounded by the following Educational institutes.

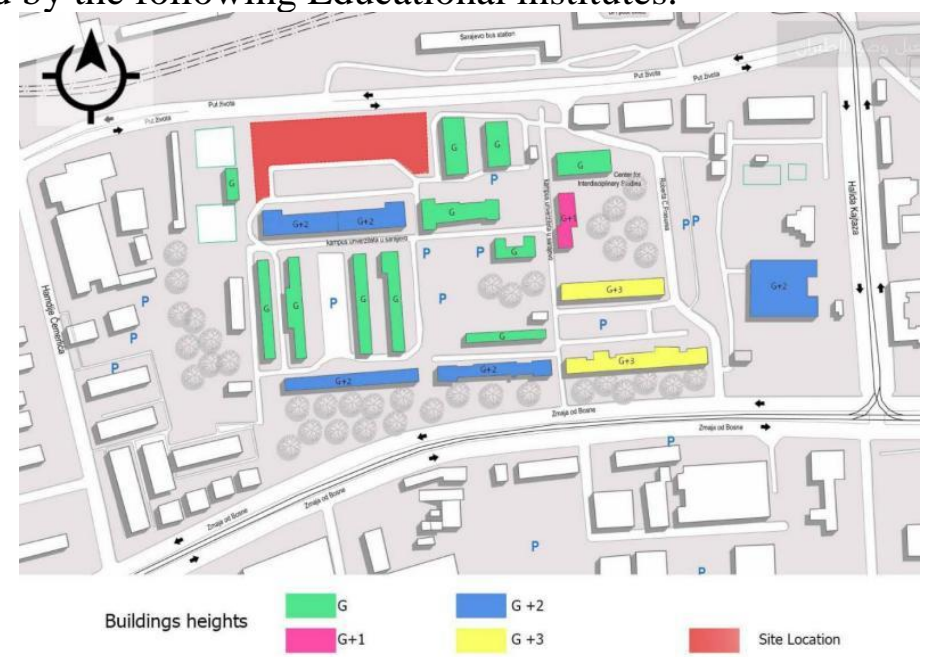

Figure 4. Site Analysis - Building Heights

Most of the surrounding buildings are low rise, no more than two or three floors, which restrict this project to a certain level of heights.

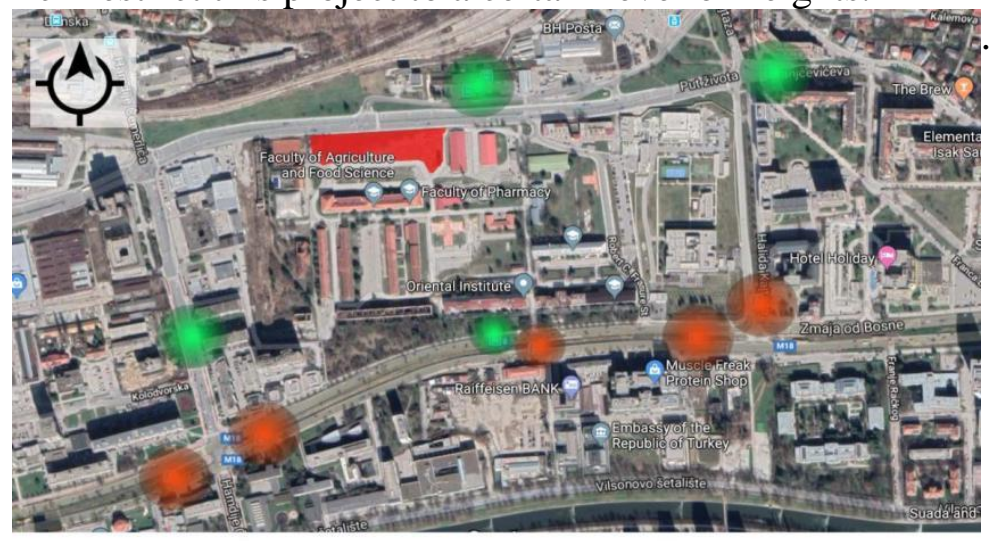

Tram stations

The site location

Figure 5. Site Analysis - Bus and Tram Stations 


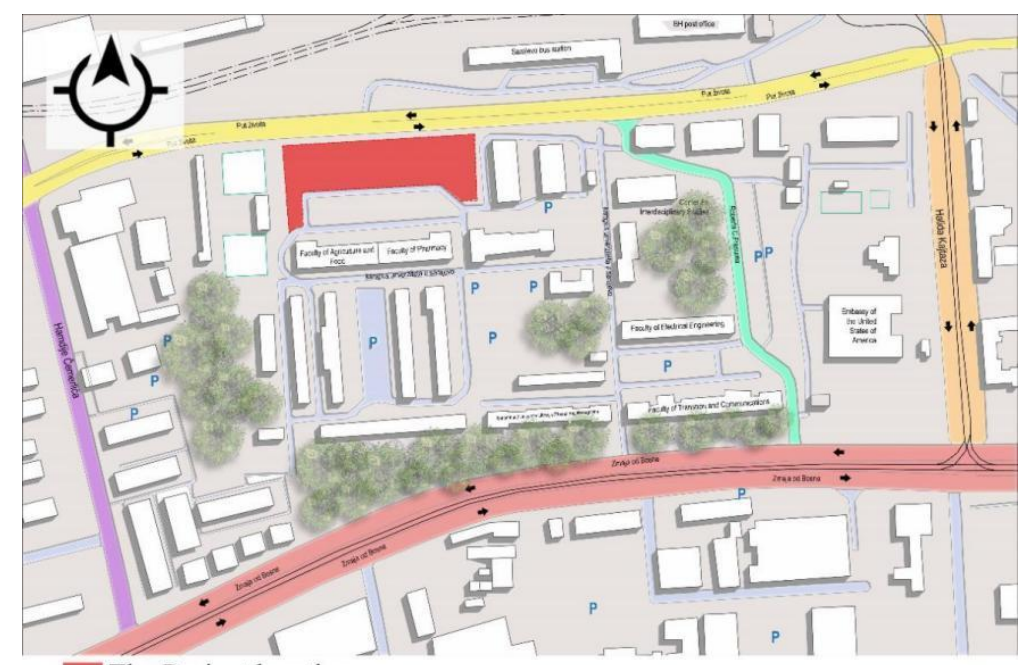

The Project location

Important street around the site:

\begin{tabular}{lll}
\hline Zmaja od Bosne & Haljda Kajtaza & Hamdije Čemerlića \\
Put Života & Roberta C.Frasure
\end{tabular}

Figure 6. Site Analysis - Circulation

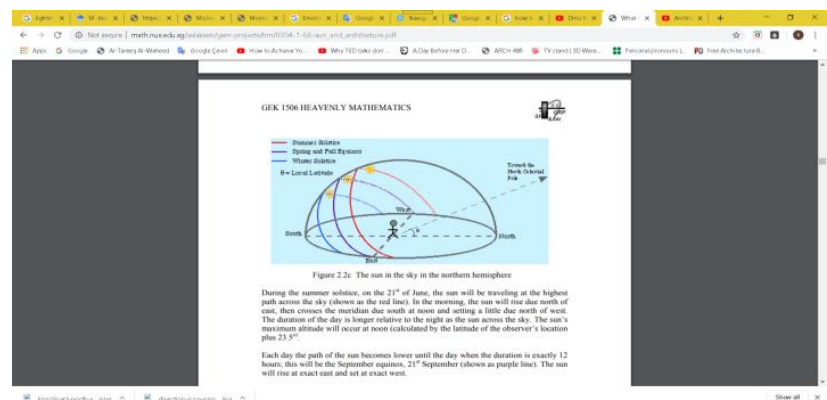

Figure 7. The Sun in the Sky in Northern Hemisphere 

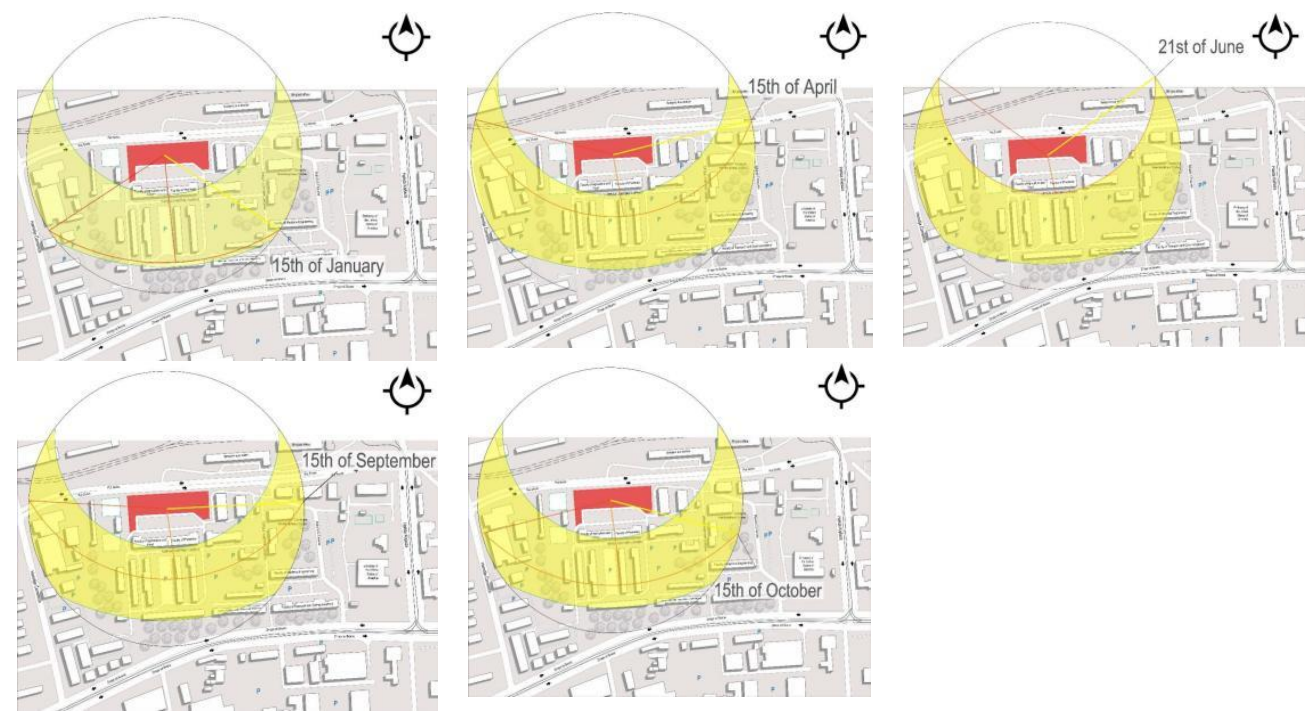

Figure 8. Sun Diagram: January $15^{\text {th }}$, April $15^{\text {th }}$, June $15^{\text {th }}$, September $15^{\text {th }}$ and October $15^{\text {th }}$. Faculty of Pharmacy. Institute of Genetic Engineering and Biotechnology.

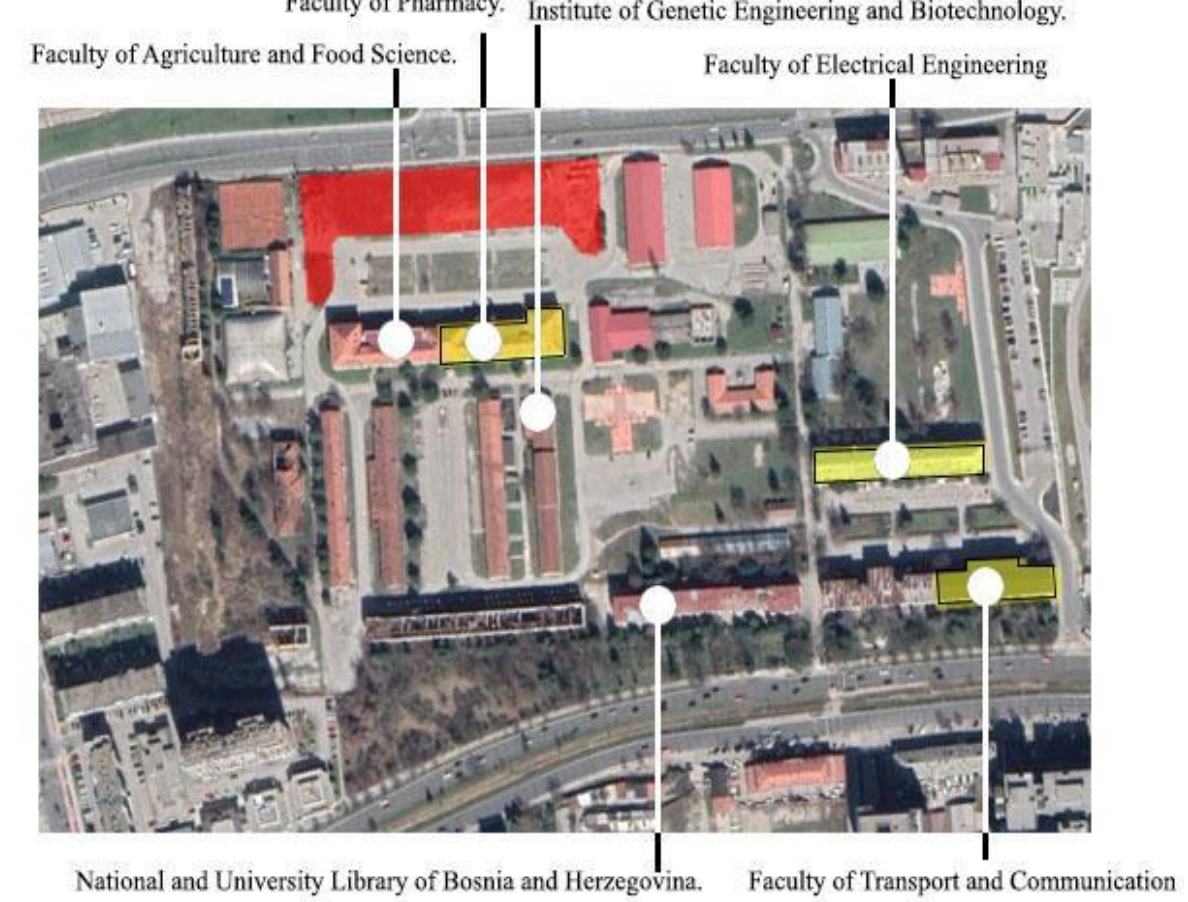

\section{The Project location}

Figure 9. Critical Analyze of Daylight Design at the Campus of Sarajevo

\subsection{Architectural Faculty}

Architectural faculty at the campus of the University of Sarajevo is designed according to the site analysis, in respect of the climate, the 
surrounding buildings, and circulation. Using the previous research as well as the appropriate architectural methods and strategies, to provide comfort and fulfill occupants' needs showed the elements that have a major impact on the design and the interior organization such as daylight, accessibility, flexibility, and spaciousness.

The building was designed in a way to feel lit, big, and spacious, avoiding long and dark corridors which feels very depressing during the cold winter. Therefore, three interior courtyards were added to the building, for providing light while connecting the inside with the outdoors.

The project consists of two parts which are connected through the main entrance lounge. On the right part there are:

On the ground floor: classrooms, offices and three interior courtyards.

On the first floor: offices, studios, exhibition and stationery store.

On the third floor: offices, studios, two amphitheaters and a gallery. And on the left part of the building there are:

On the ground floor: the main amphitheater, offices and the restaurant.

On the first floor: offices, library and computer rooms.

On the third floor: offices and two studios, connected with the right part of the building through a long hall.

\subsection{Faculty's Lighting Design Strategies \\ Buildings' Orientation}

Due to the project site and its rectangular shape, it was possible to orient the faculty along the east-west axis which allows the building to have the maximum benefits from both south and north facades. According to the literature review and articles, the southern façade is the best option for classrooms to have an efficient and uniform amount of daylight during the day [Figure 15]. It also allows the building to absorb the sun's heat energy during winter, minimizing the need for heating. Therefore, all classrooms and studios of the faculty were placed along the south façade of the building.

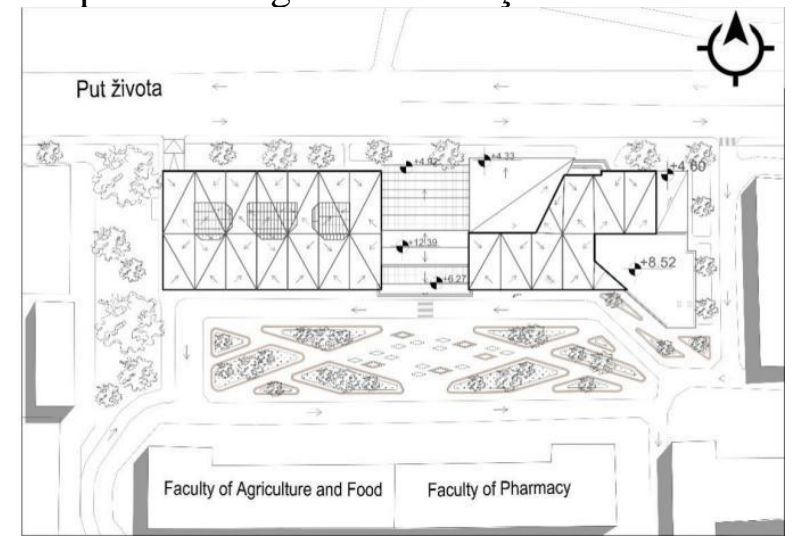

Figure 10. Project Site Plan. 


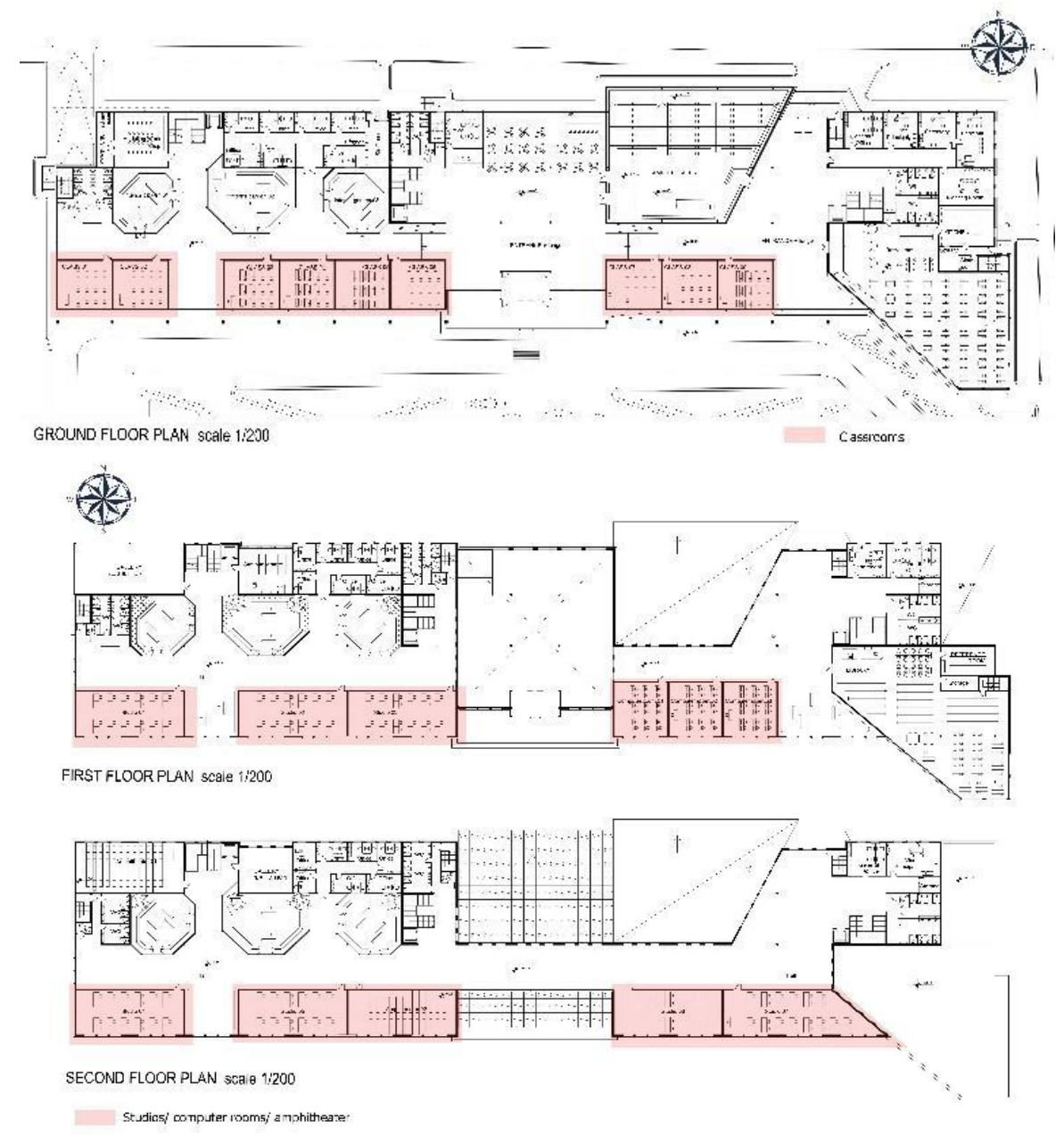

Figure 11. Orientation - Project Plans.

For the classrooms windows' proportions, in the literature review, it was advised to increase WWR to reach 35,40 , or $50 \%$, but in this study the WWR in the classroom is $33 \%$, keeping in mind windows act as heat bridge, and increasing WWR will cause more heat loss.

Windows in classrooms were divided into two parts, view windows which are the bigger part $1,75 \times 6 \mathrm{~m}$, split equally into three parts, with low visible transmittance (Tvis) $40 \%$. It has a parapet of $60 \mathrm{~cm}$. while the light window is high and has a more slender shape $0.5 \times 6 \mathrm{~m}$, with high visible transmittance (Tvis) $70 \%$. it has a parapet of 2,05m above floor level. 

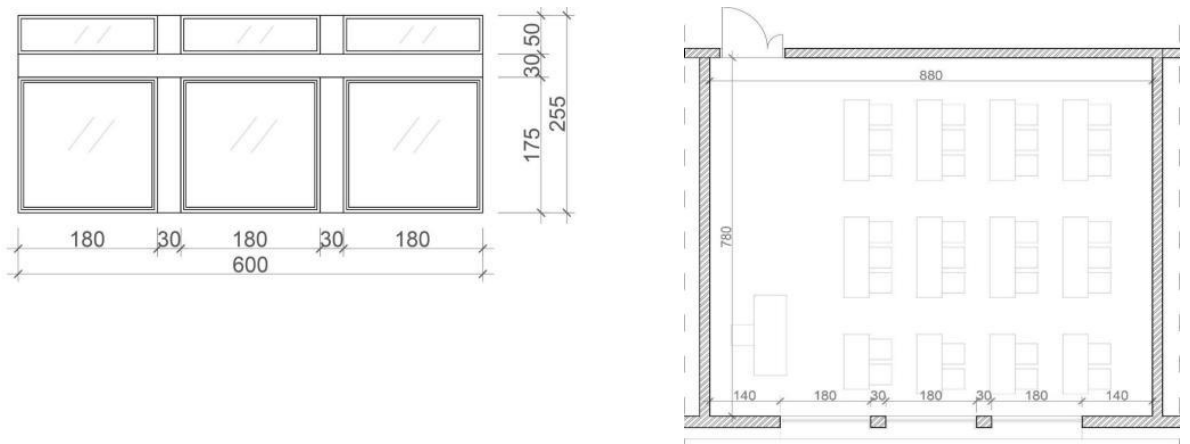

Figure 12. Classrooms Windows' Proportions and Faculty Classrooms - Ground Floor.

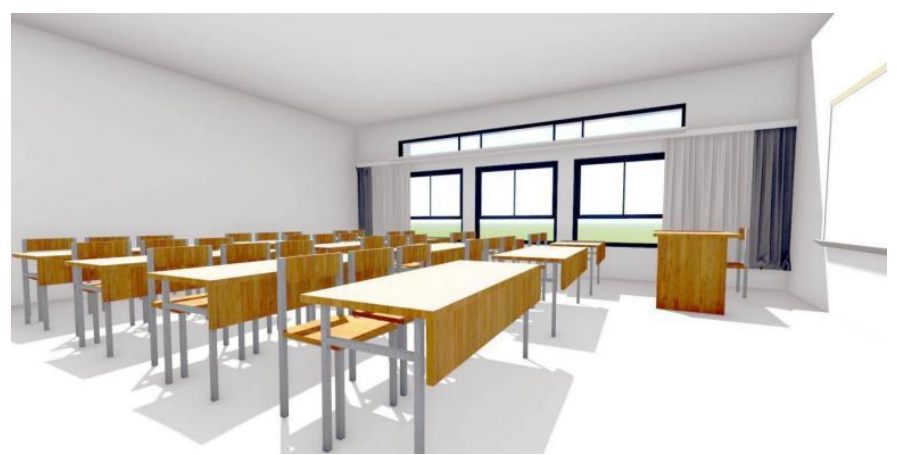

Figure 13. Classroom Render - Interior.

Windows made of low-E double glazed glass and polyvinyl chloride frame are used throughout the building. Its low U-value makes it more energyefficient, allowing daylight while protecting the building from overheating during summer, and preventing heat loss during winter.

Used for the entrance lounge, a very good lighting strategy for big spaces, the lounge height is about $7 \mathrm{~m}$. Other than providing light skylights give the feeling of openness and connection with the outside environment.

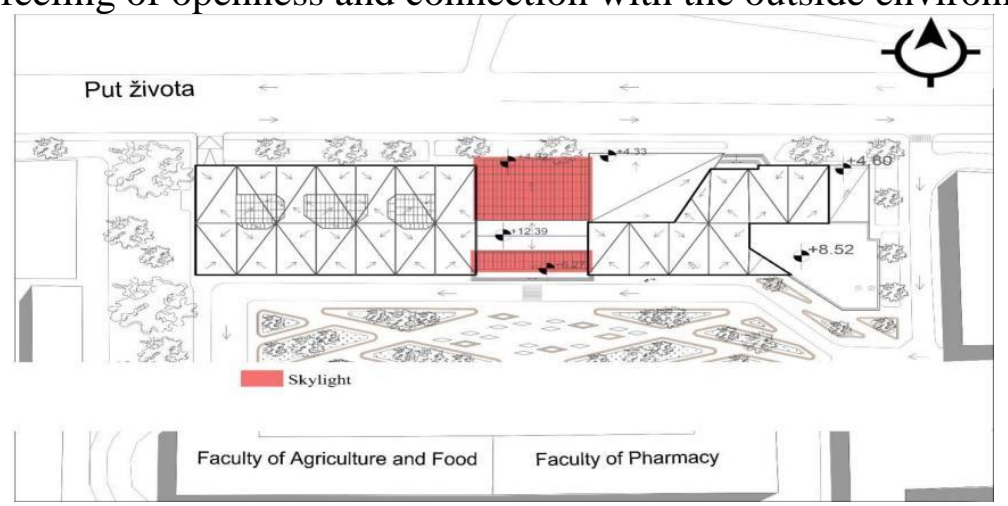

Figure 14. Site Plan - Skylights. 


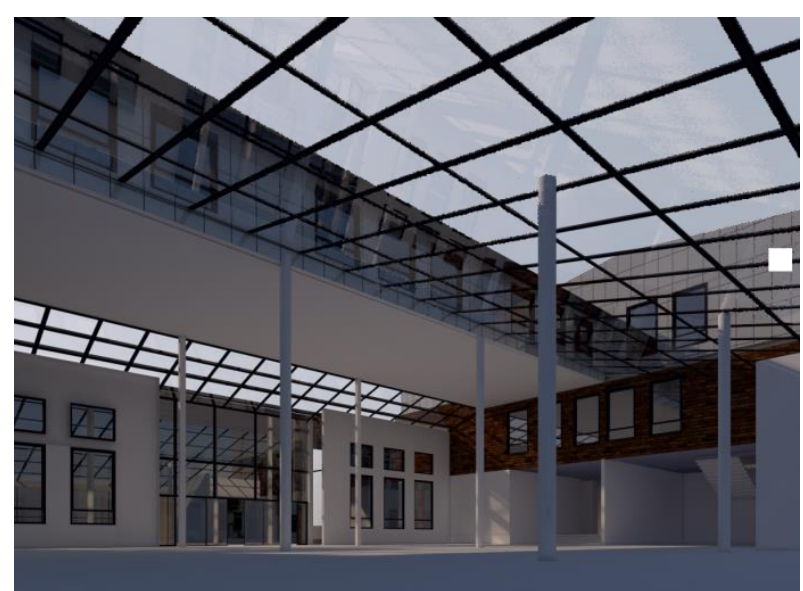

Figure 15. Project Render - Reception Lounge, Skylight.

Three atriums are added to the building through interior courtyards, to lighten the Faculty halls and avoid cold, long, and dark halls.

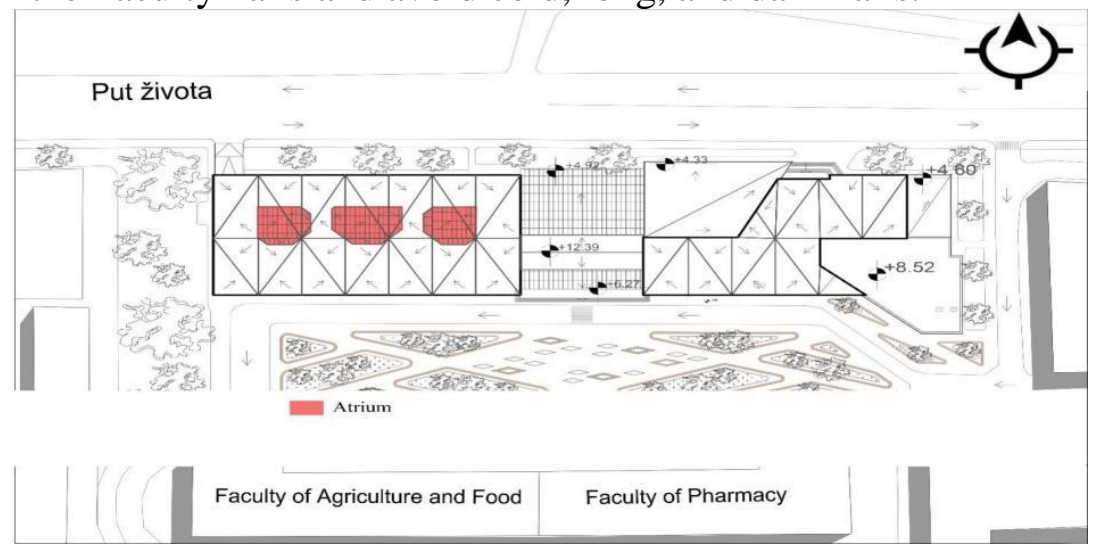

Figure 16. Site Plan - Atriums.

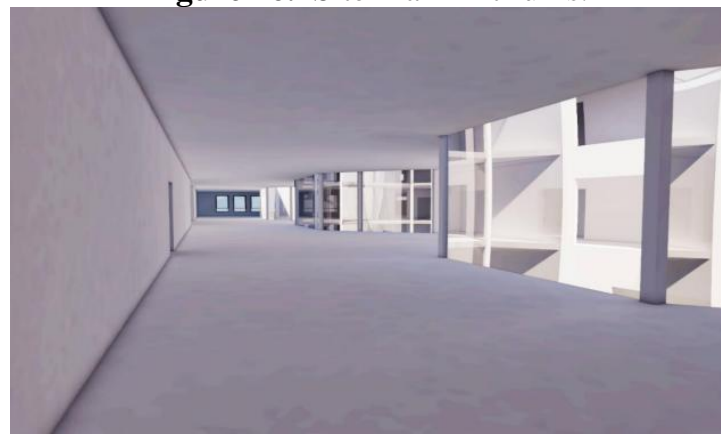

Figure 17. Faculty Render - Hallway, Atrium.

For south facade classrooms, exterior and interior light shelves are used, the exterior ones are for protection from overheating, while interior light shelves are used for reflecting light into the interior of the room. For eastern 
and western facades vertical shading elements are used along with the windows, to protect the building from overheating in the morning and afternoon.

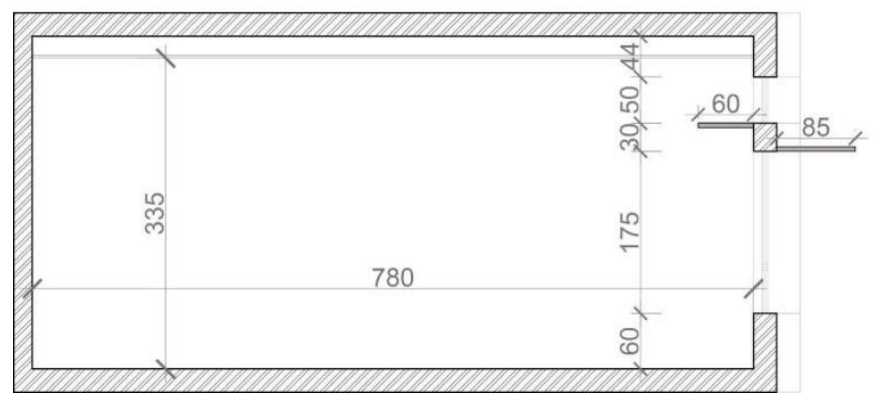

Figure 18. Classroom Section - Light Shelf.

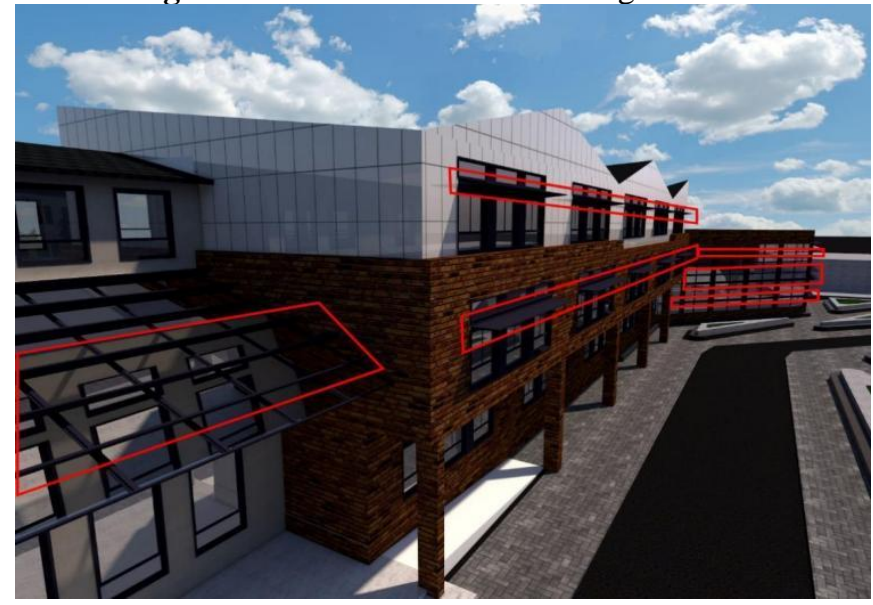

Figure 19. Faculty Render - South Façade, Shading Elements.

Even if the school has a good lighting design it still needs an artificial lighting system for rainy and cloudy days, also for late evening classes. This Architectural Faculty will be using direct-indirect luminaires, which is advised for classrooms in the literature review (Benya, 2001). LED lights are used throughout the Faculty, for their good lighting quality and energy efficiency (mentioned previously).

The presence of daylight in classrooms is usually associated with visual comfort, which is largely needed for all the visual tasks that take place in classrooms. As proved through literature the presence of daylight in classrooms can significantly impact students' health. Underexposure to daylight is associated with vitamin D deficiency, which is connected to other serious illnesses other than bone frailty. Also, daylight's role in regulating sleep, increasing attention, alertness, cognitive performances, and physical activity gives it great importance in classroom design (Shishegar \& Boubekri, 2016). 


\section{Discussion and Conclusion}

In all the studies done by Tanner (2008), Heschong, Wright, \& Okura (1999), and Nicklas \& Bailey (1996) investigating the effect of daylight on students in classrooms' settings, it was shown that daylight is significant. Daylight can be significant for students' attentiveness and concentration which will eventually enhance their academic performance. Through a literature review, it was also stated and proved that the effect of daylight is not only significant for visual performance but also the mental and physical health of students. The study done by Küller \& Lindsten (1992) proves that daylight is significant for students' hormone levels, which can affect their growth and sick leaves. These findings and information would lead architects and designers to understand the importance of daylight in classrooms, since controlling the amount of daylight accessibility have a significant effect on students' wellbeing as well as their learning outcomes.

Successful daylight design is deeply integrated with architectural design and needs to be thought about from the very beginning of the architectural process. It begins by studying the site location and shape, the surrounding buildings and vegetation, going through building regulations and standards. After that, the designing process begins, where the architect starts making decisions about the building shape and orientation for the building to make use of the location in the best way possible. Then organizing internal spaces and designing appropriate fenestration systems which covers the windows' sizes, glazing materials and type of openings (roof monitors, skylight, atrium...) is considered. After that, appropriate shading systems (interior and exterior) and artificial lighting are added. Once the designing process is over, the designer needs to follow up and supervise the construction and installation process to avoid mistakes and misinterpretation.

After site observation and analysis, problems, and issues regarding daylight design have been detected and found like inappropriate fenestration systems and shading elements, classrooms on north façades, long and dark hallways.

The purpose of architecture goes far beyond creating a shelter and putting a roof above people's heads. It has a lot to do with creating comfort when a building is made its role not only to stand and be safe but to create an appropriate environment which serves the building mission whether it is educational, commercial, or residential. Paying attention to architectural details like the color of the walls, the windows' sizes and location, thermal comfort, ventilation, and proportional spaces are essential and need to be carefully considered. This paper merely put the spotlight on one of these aspects, to assert the effect of daylight on education, and all the details that should be thought throughout the designing process. Through the literature review, it was shown that daylight design and architectural design are deeply 
connected from the beginning to the end. Besides, previous studies indicate that well-daylight classrooms can increase students' performance because of its positive impact on visual comfort, mood, and physical health.

In the end, some of the most important recommendations should be regarded and considered for enhancing the daylight design of the building (Ander, 2015):

- High windows, clerestories, or roof monitors that allow sunlight penetration from high spaces permit light deeper into space while preventing an extravagant amount of uncomfortable luminance.

- Reflecting natural light through appropriate methods or materials will increase the interior luminance and minimize the need for electrical light. Light shelves if designed right can be a good strategy for this.

- The use of sloped ceilings can help introduce more sunlight into a room.

- Avert direct sunlight for important visual tasks, intense luminance will cause discomfort and poor visibility.

- Direct light can be prevented through shading systems, which can also help to distribute it.

- Understanding orientations, and the use of shading elements. For example, light shelves are highly effective for south facades, but not so much for east or west facades.

\section{References:}

1. Aan Het Rot, M., Benkelfat, C., Boivin, D. B., \& Young, S. N. (2008). Bright light exposure during acute tryptophan depletion prevents a lowering of mood in mildly seasonal women. European Neuropsychopharmacology, 18(1), pp. 14-23.

2. American Institute of Architects. (1982). Daylighting. The Institute.

3. Ander, G. D. (2015, 09 15). Daylight Retrieved 08 21, 2019, from https://www.wbdg.org/resources/daylighting

4. Antonius, R. (2003). Interpreting Quantitative Data with SPSS. Sage Publications Ltd.

5. Aries, M. B., Aarts, M. P., \& van Hoof, J. (2015). Daylight and health: A review of the evidence and consequences for the built environment. Lighting Research \& Technology, 47(1), pp. 6-27.

6. Augustyn, A. (2019). Sarajevo NATIONAL CAPITAL, BOSNIA, AND HERZEGOVINA. Retrieved August 09, 2019, from Britannica: https://www.britannica.com/place/Sarajevo

7. Boubekri, M., Cheung, I. N., Reid, K. J., Wang, C. H., \& Zee, P. C. (2014). Impact of windows and daylight exposure on overall health and sleep quality of office workers: a case-control pilot study. Journal of clinical sleep medicine, 10(06), pp. 603-611. 
8. Boyce, P. (1998). Why daylight. In Proceedings Daylight 98, International Conference on Daylighting Technologies for Energy Efficiency in Buildings, Ottawa, Ontario, Canada.

9. Boyd, R. A. (1957). U.S. Patent No. 2,812,691. Washington, DC: U.S. Patent and Trademark Office.

10. Cammarano, S., Pellegrino, A., Lo Verso, V. R. M., \& Aghemo, C. (2015). Assessment of daylight in rooms with different architectural features. Building Research \& Information, 43(2), pp. 222-237.

11. Creswell, J. W. (2009). Research Design: Qualitative, Quantitative, and Mixed Method Approaches. Sage Publications Ltd.

12. Crossman, A. (2018). What Is Qualitative Research?. Retrieved from https://www.thoughtco.com/qualitative-research-methods-3026555

13. De Luca, F., Voll, H., \& Thalfeldt, M. (2016). Horizontal or vertical? Windows' layout selection for shading devices optimization. Management of Environmental Quality: An International Journal, 27(6), pp. 623-633.

14. Devlin, A. S., \& Arneill, A. B. (2003). Health care environments and patient outcomes: A review of the literature. Environment and Behavior, 35, pp. 665-694.

15. Dubois, M. C. (2009). Effect of glazing types on daylight quality in interiors: conclusions from three scale model studies. Experiencing Light.

16. Dubois, M. C., Cantin, F., \& Johnsen, K. (2007). The effect of coated glazing on visual perception: A pilot study using scale models. Lighting Research \& Technology, 39(3), pp. 283-304.

17. Edwards, L., \& Torcellini, P. (2002). Literature review of the effects of natural light on building occupants (No. NREL/TP-550-30769). National Renewable Energy Lab., Golden, CO.(US).

18. Efficient Windows Collaborative. (2019). WINDOW TECHNOLOGIES: Glass. Retrieved 10 12, 2019, from commercial windows. org: https://www.commercialwindows.org/vt.php

19. Gifford, R., Hine, D. W., \& Veitch, J. A. (1997). Meta-analysis for environment-behavior research, illuminated with a study of lighting level effects on office task performance. In G. T. Moore \& R. W. Marans (Eds.), Advances in environment, behavior, and design (Vol. 4). New York: Plenum. pp. 223-253.

20. Godhamgaonkar, A. (2005). Improving Daylight Illumination and Energy Efficiency Using an Atrium in a Mixed-Use Building. Published Master thesis, The University of Arizona.

21. Green Passive Solar Magazine. 2012. Orientation / South Facing Windows. Accessed09 
09,2019.https://greenpassivesolar.com/passivesolar/buildingcharacter istics/orientation-south-facing-windows/.

22. Cohen, S., Kessler, R. C., \& Gordon, L. U. (1997). Strategies for measuring stress in studies of psychiatric and physical disorders. In $\mathrm{S}$. Cohen, R. C. Kessler \& L. U. Gordon (Eds.), Measuring stress: A guide for health and social scientists (pp. 3-26). New York: Oxford University Press.

23. Haglund, K. L. (2010, April). Window selection methodologies and optimization in high-performance commercial buildings. In Building Enclosure Science \& Technology Conference (BEST2), Fenestration (Vol. 1), pp. 12-24.

24. Hathaway, W. E., Hargreaves, J. A., Thompson, G. W., \& Novitsky, D. (1992). A study into the Effects of Light on children of Elementary School Age. Alberta Education.

25. Hee, W. J., Alghoul, M. A., Bakhtyar, B., Elayeb, O., Shameri, M. A., Alrubaih, M. S., \&Sopian, K. (2015). The role of window glazing on daylighting and energy saving in buildings. Renewable and Sustainable Energy Reviews, 42, pp. 323-343.

26. Heschong, L., Wright, R. L., \& Okura, S. (2002). Daylighting impacts on human performance in school. Journal of the Illuminating Engineering Society, 31(2), pp. 101-114.

27. Holick, M. F. (2008). Photobiology and non-calcemic actions of vitamin D. In Principles of Bone Biology (pp. 795-811). Academic Press.

28. Ibrahim, N., \& Hayman, S. (2005, April). Daylight design rules of thumb. In Conference on Sustainable Building South East Asia (Vol. 11, p. 13).

29. Ibrahim, N., \& Zain-Ahmed, A. (2007, September). Daylight availability in an office interior due to various fenestration options. In 2nd PALENCIA Conference and 28th AIVC Conference on Building Low Energy Cooling and Advanced Ventilation Technologies in the 21st Century, Crete island, Greece (Vol. 1), pp. 436-440.

30. Kaplan, R. (1993). The role of nature in the context of the workplace. Landscape and Urban Planning, 26, pp. 193-201.

31. Kingspan insulation UK. (2016, 105$)$. What are $U$-values, $R$-values, and lambda values? Retrieved 09 12, 2019, from kingspan.com: https://www.kingspan.com/gb/en-gb/products/insulation/kingspaninsight/articles-and-advice/what-are-u-values-r-values-and-lambdavalues

32. Küller, R., \& Lindsten, C. (1992). Health and behavior of children in classrooms with and without windows. Journal of Environmental Psychology, 12(4), 305-317. 
33. Lacan, I., \& McBride, J. R. (2009). War and trees: The destruction and replanting of the urban and peri-urban forest of Sarajevo, Bosnia and Herzegovina. Urban Forestry \& Urban Greening, 8(3), pp. 133-148.

34. Lam, W. M. C., Ripman, C. H. (1992). Perception and lighting as formgivers for architecture. New York: Van Nostrand Reinhold.

35. Lansdowne, A. T., \& Provost, S. C. (1998). Vitamin D3 enhances mood in healthy subjects during winter. Psychopharmacology, 135(4), pp. 319-323.

36. Littlefair, P. J. (1995). Light shelves: computer assessment of daylighting performance. International Journal of Lighting Research and Technology, 27(2), pp. 79-91.

37. Lorie. 2018. Daylight \& Sustainable Design. 08 28. Accessed 09 06, 2019. https://homeenergyheroes.com/2018/08/28/daylightingsustainable-design/.

38. Mangkuto, R. A., Rohmah, M., \& Asri, A. D. (2016). Design optimization for window size, orientation, and wall reflectance with regards to various daylight metrics and lighting energy demand: A case study of buildings in the tropics. Applied energy, 164, pp. 211-219.

39. McLeod, A. (2017). Types of Research Approaches. Retrieved from https://www.google.ba/search? source=hp\&ei=u8tAXJLhDMWhsAH 63qn4CA\&q=mcleod $+2017+$ types + of + research \&btnK=Google+Sear ch\&oq=mcleod+2017+types+of+research\&gs_l=psyab.3...100743.111005..111230...14.0..0.379.5175.0j37j1j1.....0....1..g wswiz....6..35i39j0j0i67j0i10j0i22i30j33i160j33i13i21j33i21j33i22i29i 30.4FnI5Zq2BB0

40. Molinski, M. 2009. Daylighting: Overcoming Glare and Heat $\begin{array}{lllllll}\text { Challenges. } & 1 & 1 & \text { Accessed } 09 & 04 & \end{array}$ https://www.facilitiesnet.com/lighting/article.aspx?id=10448\&off104 48

41. Mott, M. S., Robinson, D. H., Walden, A., Burnette, J., \& Rutherford, A. S. (2012). Illuminating the effects of dynamic lighting on student learning. Sage Open, 2(2), 2158244012445585.

42. Navvab, M. \& Selkowitz, S. (1984). Daylighting data for atrium design. Proceedings of the 9th National Passive Solar Conference, Columbus, OH, pp. 495-500.

43. Nicklas, M. H., \& Bailey, G. B. (1996). Analysis of the performance of students in daylit schools. Research Report, Innovative Design, pp.6.

44. O'Brien, W., Kapsis, K., and Athienitis, AK. (2013), Manuallyoperated window shade patterns in office buildings: a critical review, Building and Environment, Vol. 60, February, pp. 319-338. 
45. OECD. Publishing, \& International Energy Agency. (2006). Energy technology perspectives: Scenarios and strategies to 2050. Organization for Economic Co-operation and Development.

46. Olgyay, V. \& Olgyay, A. (1957), Solar Control and Shading Devices, Princeton University Press, Princeton, NJ.

47. Ott, J. N. (1976). Influence of fluorescent lights on hyperactivity and learning disabilities. Journal of Learning Disabilities, 9(7), pp. 417422.

48. Parmar, R. (2019). Importance of Building Orientation in Architecture. Retrieved July 30, 2019, https://gharpedia.com/importance-ofbuilding-orientation-in-architecture/

49. Parpairi, K., Baker, N., \& Steemers, K. (2000). Daylighting quality through user preferences: Investigating libraries. In Proceedings of PLEA, pp. 611-616.

50. Plympton, P., Conway, S., Epstein, K. (2000). Daylighting in Schools: Improving student performance and health at a price schools can afford. American Solar Energy Society Conference. Madison, Wisconsin, National Renewable Energy Laboratory.

51. Pulay, A. S. (2010). Awareness of Daylighting on Student Learning in an Educational Facility. University of Nebraska - Lincoln, Lincoln.Rea, M. S. (2000). The IESNA lighting handbook: reference $\&$ application.

52. Robbins, C. L. (1985). Daylighting. Design and analysis. United States. Van Nostrand Reinhold, New York, NY, pp. 3-188.

53. Ruck, N., Aschehoug, O., Aydinli, S., Christoffersen, J., Courret, G., Edmonds, I., ... \& Michel, L. (2000). Daylight in Buildings-A sourcebook on daylighting systems and components. Lawrence Berkeley National Laboratory, 9910-47493.

54. Samani, S. A., \& Samani, S. A. (2012). The impact of indoor lighting on students' learning performance in learning environments: A knowledge internalization perspective. International Journal of Business and Social Science, 3(24).

55. SEPCO. (2013). The Advantages of LED Lights for the Environment. Retrieved July 31, 2019, from sepco-solar lighting: https://www.sepco-solarlighting.com/blog/bid/145611/theadvantages-of-led-lights-for-the-environment

56. Shishegar, N., \& Boubekri, M. (2016, April). Natural light and productivity: Analyzing the impacts of daylighting on students' and workers' health and alertness. In Proceedings of the International Conference on "Health, Biological and Life Science"(HBLS-16), Istanbul, Turkey, pp. 18-19. 
57. Tanner, C. K. (2008). Explaining relationships among student outcomes and the school's physical environment. Journal of advanced academics, 19(3), pp.444-471.

58. Urlaub, S. \& Grün, G. \& Foldbjerg, P.\& Sedlbauer, K. (2016). The impact of ventilation and daylight on learning in schools - a summary of the actual state of knowledge.

59. Vandewalle, G., Balteau, E., Phillips, C., Degueldre, C., Moreau, V., Sterpenich, Peigneux, P. (2006). Daytime light exposure dynamically enhances brain responses. Current Biology, 16(16), pp.1616-1621.

60. Vandewalle, G., Gais, S., Schabus, M., Balteau, E., Carrier, J., Darsaud, A., \& Maquet, P. (2007). Wavelength-dependent modulation of brain responses to a working memory task by daytime light exposure. Cerebral cortex, 17(12), pp.2788-2795.

61. Vandewalle, G., Schmidt, C., Albouy, G., Sterpenich, V., Darsaud, A., Rauchs, G., ... \& Maquet, P. (2007). Brain responses to violet, blue, and green monochromatic light exposures in humans: the prominent role of blue light and the brainstem. PloS one, 2(11), e1247.

62. Velux. (2016). Benefits of Daylight. Retrieved July 31, 2019, from Velux: https://www.velux.com/our-company/privacy-statement

63. Veitch, J. A., \& Galasiu, A. D. (2012). The physiological and psychological effects of windows, daylight, and view at home: review and research agenda. Research Report. National Research Council of Canada. Institute for Research in Construction.

64. Veitch, J. A., \& Newsham, G. R. (1998). Lighting quality and energyefficiency effects task performance, mood, health, satisfaction, and comfort. Journal of the Illuminating Engineering Society, 27(1), pp.107-129.

65. Wurtman, R. J. (1975). The effects of light on the human body. Scientific American, 233(1), pp. 68-79.

66. Zomorodian, Z. S., Korsavi, S. S., \& Tahsildoost, M. (2016). The effect of window configuration on daylight performance in classrooms: A field and simulation study. دانشخاه علم و صنعت ايران,26(1), pp. 15-24. 